\title{
Predicting martian mineral compositions in situ: Crystal chemical techniques
}

Shaunna M. Morrison, ${ }^{a}$ Robert T. Downs, ${ }^{b}$ David F. Blake, ${ }^{c}$ David T. Vaniman, ${ }^{d}$ Douglas W. Ming, ${ }^{e}$ Allan H. Treiman, ${ }^{f}$ Cherie N. Achilles, ${ }^{9}$ Robert M. Hazen, ${ }^{a}$ Albert S. Yen, ${ }^{h}$ Richard V. Morris, ${ }^{e}$ Elizabeth B. Rampe, ${ }^{\mathrm{e}}$ Thomas F. Bristow,${ }^{\mathrm{c}}$ Steve J. Chipera, ${ }^{\mathrm{i}}$ Nicholas Castle, ${ }^{f}$ Valerie Tu, ${ }^{\mathrm{e}}$ and Richard Walroth. ${ }^{\mathrm{c}}$

aGeophysical Laboratory, Carnegie Institution, 5251 Broad Branch Rd NW, Washington, DC, 20015 USA, smorrison@carnegiescience.edu

bUniversity of Arizona, 1040 E 4th St, Tucson, AZ, 85721 USA

'NASA Ames Research Center, Moffett Field, CA 94035, USA

dPlanetary Science Institute, 1700 E. Fort Lowell, Tucson, AZ 85719-2395, USA

eNASA Johnson Space Center, Houston, TX, 77058 USA

fLunar and Planetary Institute, 3600 Bay Area Blvd, Houston, TX 77058, USA

gNASA Goddard Space Flight Center, 8800 Greenbelt Rd, Greenbelt, MD 20771, USA

hJet Propulsion Laboratory, California Institute of Technology, 4800 Oak Grove Drive, Pasadena, CA 91109, USA

'Chesapeake Energy Corporation, 6100 N. Western Avenue, Oklahoma City, OK 73118, USA

The Mars Science Laboratory rover, Curiosity, is providing in situ analyses of rocks and soils in Gale crater. Since landing in 2012, Curiosity has analyzed the mineralogy of sediments with the CheMin instrument, the first X-ray diffractometer on another planet [1]. CheMin performs quantitative mineralogical analyses of drilled powders and scooped sediment to determine mineral abundances and unit-cell parameters of major crystalline phases with Rietveld refinement of the XRD patterns.

In order to better understand the formational conditions and geologic history of the minerals found in Gale crater, the CheMin team developed crystal-chemical methods to predict the chemical compositions of minerals observed in the CheMin samples [2,3]. The main crystalline phases identified by CheMin include plagioclase (average $A n_{40}$ ), sanidine (average $\mathrm{Or}_{74}$ ), pigeonite (average $\quad \mathrm{Mg}_{1.18(19)} \mathrm{Fe}_{0.72(7)} \mathrm{Ca}_{0.10(9)} \mathrm{Si}_{2} \mathrm{O}_{6}$ ), $\quad \mathrm{C} / \mathrm{c}$ clinopyroxene (average $\mathrm{Mg}_{0.96(6)} \mathrm{Ca}_{0.73(2)} \mathrm{Fe}_{0.31(8)} \mathrm{Si}_{2} \mathrm{O}_{6}$ ), orthopyroxene (average $\mathrm{Mg}_{0.79(6)} \mathrm{Fe}_{1.20(6)} \mathrm{Ca}_{0.01(2)} \mathrm{Si}_{2} \mathrm{O}_{6}$ ), olivine (average $\mathrm{Fo}_{60}$ ), magnetite, and alunite-jarosite group minerals [4].

The mineralogy of analyzed samples plays a key role in characterizing various 3.5 billion year old fluvio-lacustrine paleoenvironments in Gale crater. Together with findings from other instruments on Curiosity, CheMin has documented mineralogical details of the first habitable environment found on another planet [4].

[1] D.F. Blake et al. (2013) Science 341, 1239505

[2] D.T. Vaniman et al. (2014) Science 343, 1243840

[3] Morrison et al. (2017) Am Min, 103(6): 848-856

[4] Morrison et al (2017) Am Min, 103(6): 857-871 